DOI: https://doi.org/10.32839/2304-5809/2021-7-95-9

УДК 378.046.4.

Хоружа Л.Л., Ярова І.Б.

Київський університет імені Бориса Грінченка

\title{
ПРОБЛЕМА СТВОРЕННЯ ЕЛЕКТРОННОГО ПІДРУЧНИКА ДЛЯ ВИЩОЇ ШКОЛИ В УМОВАХ СУЧАСНИХ ПАРАДИГМАЛЬНИХ ЗМІН
}

\begin{abstract}
Анотація. У статті розглянуто особливості підручникотворення в епоху парадигмальних змін, окреслено основні особливості парадигмальних зміни XXI століття, що суттево впливають на свідомість та особливості мислення сучасного покоління, наведено основні характеристики покоління «Z». Сучасні дослідники активно вивчають особливості світобачення різних поколінь з метою адаптації навчальних програм до їхніх вимог та запитів часу. У статті викладено результати опитування студентів щодо бачення найзручнішого електронного підручника та з'ясовано, що сучасні університети практично не задовольняють потреб студентів щодо наявності електронних підручників, а наявні екземпляри найчастіше є скан-копією паперового варіанту. На основі опитування студентів, у статті висвітлено основні вимоги до електронного підручникотворення в епоху парадигмальних змін.
\end{abstract}

Ключові слова: підручникотворення, електронний підручник, парадигмальні зміни, покоління «Z», студентоцентризм.

Khoruzha Lyudmila, Yarova Ilona Borys Grinchenko Kyiv University

\section{THE PROBLEM OF CREATING AN ELECTRONIC TEXTBOOK FOR HIGHER EDUCATION IN THE CONDITIONS OF MODERN PARADIGMAL CHANGES}

Summary. The article considers the peculiarities of textbook creation in the era of paradigmatic changes, outlines the main features of paradigmatic changes of the XXI century, which significantly affect the consciousness and thinking of the modern generation. Soviet, state-oriented pedagogy was replaced by personally-oriented pedagogy. Also, the conditions of technical development, globalization and informatization affect new generations and demands of the labor market. The main characteristics of generation "Z" are given in the article. Such features include decreased concentration, fragmentary perception and memorization of material, low levels of socialization and empathy, reduced value of education. Modern researchers are actively studying the peculiarities of the worldview of different generations in order to adapt curricula to their requirements and demands of the time. The use of gadgets in the educational process is not only a convenience but also a necessity given the informatization of modern society, for which it is necessary to train professionals with appropriate competence. The article presents the results of a survey of students about the vision of the most convenient electronic textbook and found that modern universities do not meet the needs of students for electronic textbooks, and available copies are often a scanned copy of the paper version and do not meet the educational needs of students. Based on a survey of students, the article highlights the basic requirements for electronic textbook creation in an era of paradigmatic change. The main features are the structuring of the material, the use of infographics, the ability to manipulate the electronic textbook, such as searching for information by keywords, adjusting the font size and color of the pages. Also important is the ability to highlight basic information, add notes, as well as the availability of an audio version of the information and a large amount of visual material, links to sources. It is also an opportunity to perform tasks and send it for verification immediately in the textbook. One of the important components is the ability to use electronic textbooks for students with special educational needs. Keywords: textbook creation, electronic textbook, paradigm shifts, generation "Z", student-centeredness.

Постановка проблеми. Поняття електронний підручник з'явилося нещодавно, але швидко привернуло увагу дослідників 3 різних галузей науки як в Україні, так і закордоном. Значний вплив парадигмальних змін, а також нерозповсюджена практика використання спеціалізованих методів створення свідчить про недостатній рівень аналізу цієї категорії й розуміння важливості її використання в освіті вищої школи, що зумовлюе актуальність обраної теми.

Метою статті $є$ визначення особливостей створення електронних підручників для вищої школи в умовах парадигмальних змін.

Реалізація поставленої мети передбачає виконання таких завдань:

1) проаналізувати особливості парадигмальних змін в освіті;

2) визначити сутність і цільове призначення електронних підручників;
3) окреслити дидактичні засади побудови, інструменти та особливості створення електронних підручників для вищої школи.

Аналіз останніх досліджень i публікацій. Справді важливими для сучасного підручникотворення є дослідження особливостей підручникотворення Юлії Шлапак, у їі праці «Електронний підручник (посібник): стан $і$ перспективи в Украӥніл. Цьому питанню присвячені наукові розвідки I. Гайдаєнко, С. Грищенко, С. Сивоєвої, В. Редько і інших.

Однак, більшість аспектів створення електронних сучасних підручників залишаються недостатньо висвітленим і потребують подальшого дослідження і розвитку.

Виділення не вирішених раніше частин загальної проблеми. Вимоги до найсучаснішого електронного підручника для вищої школи, що відповідатиме не лише навчальній програмі, а й особливостям мислення покоління «Z» та запитам сучасних студентів. 
Виклад основного матеріалу. Парадигмальні зміни сучасного світу, спричинені стрімким розвитком індрормаційних технологій, впливають на всі серери життя, зокрема й на освітню. На зміну радянській, державно-зорієнтованій педагогіці, приходить новаторська, особисто-зорієнтована, тому студентоцентризм стае базисом навчального процесу у вищій школі й парадигма авторитаризму змінюеться парадигмою маніпулятивної педагогіки, коли студент є не тільки об'єктом, а й суб'єктом педагогічної діяльності. Відповідно до џого виникає й гуманістична парадигма, а за нею - інфрормаційно-комп'ютерна [2].

Покоління, яке народилось у період активного становлення останньої 3 названих парадигм в повсякденне життя називається поколінням "Z" і саме воно яскраво демонструе зміни особливості світогляду й сприймання інформації, спричинені модернізацією сучасних технологій.

Так, міленіали, на відміну від представників старших поколінь "X" та "Y", народилися в період, коли інформаційні технології вже стали невіддільними побутовими супутниками. Вони звикли, що в будь-якому місці й у будь-який час можуть отримати доступ до інформації, комунікації тощо. Це спричинило зміни схеми запам'ятовування нових знань, адже постійний доступ до матеріалу зменшуе необхідність вивчити його, перевівши фокус на відкладання в пам'яті ресурсу, де можна освіжити знання [1].

Важливо зазначити й зменшення концентрації уваги, адже великий потік інформації сприяє розсіянню зосередження та фррагментарному сприйманню матеріалу, яке передбачає бачення світу не цілісним, а лише набором не пов'язаних між собою явищ, саме так виражається кліпове мислення.

Постійне використання інтернету призводить i до того, що люди все менше часу відводять на живу комунікацію надаючи перевагу онлайн чатам. Відповідно, рівень соціалізації та емпатії досить низький [1].

Безперечно, ціннісні орієнтири представників покоління “ $Z$ ” також відрізняються від їхніх попередників, наприклад, вони вже не вважають, що диплом є обов'язковою складовою успішного кар'ерного росту й бачать можливості отримання роботи без отримання вищої освіти. Тому, міленіали часто нехтують освітнім процесом, а зневірившись можуть легко покинути навчання взагалі.

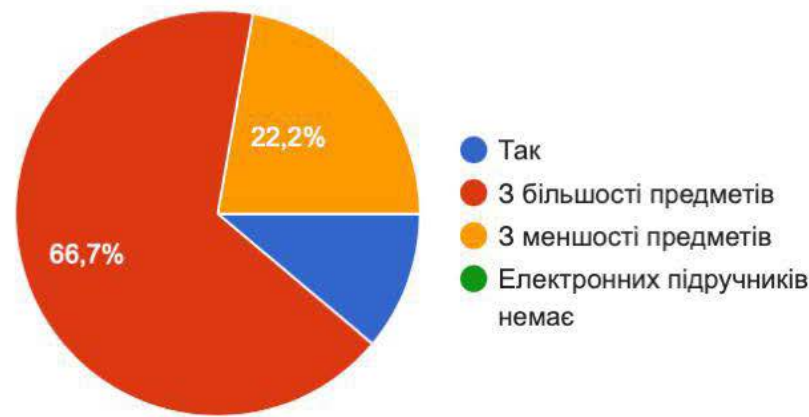

Рис. 1. Чи з усіх предметів наявні електронні версії підручника?

Джерело: опитування студентів в гугл-ббормі
Оскільки, на відміну від учнів у школі, студенти мають опрацьовувати більшість матеріалу самостійно, а значить, активно користуються підручниками. 3 давніх часів він лишаеться невіддільною й надважливою складовою навчального процесу й в епоху парадигмальних змін знаходить своє втілення й в електронному форматі. I вищенаведені особливості покоління “Z” мають враховуватися при їх створенні. Однак, попри праці різних науковців, які запропонували своє бачення вимог до електронного підручника та наказу Міністерства Освіти й науки України "Про затвердження Положення про електронний підручник" від 2018 р., електронні посібники й досі не набули такої популярності серед здобувачів вищої освіти, на відміну від школярів, які все активніше поглинають інформацію за допомогою нових електронних посібників.

Такий формат сучасних підручників сприяе розвитку не лише профресійної, але й цифрової компетентності, забезпечує доступність до навчального матеріалу, зручність використання, можливість активізувати інтерес та сконцентрувати увагу за допомогою мультимедійних технологій, полегшити процес перевірки набутих знань і організацію навчального процесу, підлаштувати подачу інформації до особливостей сприймання покоління “Z”, забезпечуе можливість впровадження принципу індивідуалізованого навчання, а також охороняе навколишне середовище від вирубки дерев.

3 метою виявлення шляхів модернізації вже наявних електронних підручників у вищій школі, нами було проведене опитування серед студентів Київського університету імені Бориса Грінченка. Його результати є важливими для розуміння теми нашої роботи й формування вимог до електронного підручника.

По-перше, важливим $є$ й відсутність чіткої класифікації електронних підручників, адже більшість викладачів і досі певні, що це е просто цифровою версією паперового екземпляра, адже абсолютно всі студенти відповіли, що хоча й практично всі дисципліни забезпечені електронними підручниками (рис. 1), але вони мають саме скан-копію або передрук паперової версії підручника, а не створений на спеціальній платформі 3 різними мультимедійними та інтерактивними технологіями посібник (рис. 2).

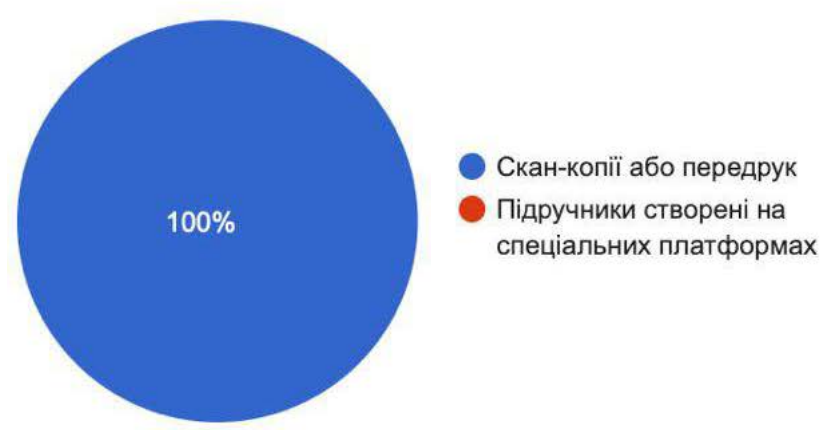

Рис. 2. Чи е наявні електронні підручники скан-копіею або передруком паперового підручника чи створені на спеціальних

платформах з використанням мультимедійних, інтерактивних і ігрових технологій?

Джерело: опитування студентів в гугл-формі 
Попри це, студентам все одно зручніше працювати 3 електронною версією підручника, навіть якщо наявна паперова версія в домашній бібліотещі, адже вони вважають, що електронний підручник дозволяе вивчати предмет у дорозі за допомогою гаджетів, при будь-якому освітленні, не потребує збільшувати вагу сумки паперовою версією, можна легко отримати доступ дистанційно до підручника, наявна можливість швидко знаходити інформацію, можна збільшувати шриорт, розширювати можливості користування підручником закладками, кольоровими помітками, скріншотами, замітками тощо. Також, деякі зі студентів відмітили екологічність використання електронних підручників, адже для їх виготовлення не потрібно вирубувати дерева. Єдиними недоліками, які були відмічені, виявились питання про необхідність забезпечення постійного живлення гаджетів, стомлення очей та непристосованість для людей з особливими освітніми потребами (рис. 3).

Тому, оскільки студенти часто мають саме скан-копію паперової версії підручника, то вони б воліли аби їх передрукували, щоб мати змогу копіювати текст для своїх презентацій або електронних конспектів, шукати швидко матеріал за допомогою команди “control+f”, виділяти важливу інорормацію кольором під час читання (якщо це скан-копії, де це неможливо), додавати закладки та зробити гіперпосилання на тематичні блоки. Деякі зі студентів відмітили й необхідність доступного фрормату підручників, адже більшість з них вони змушені фрорматувати вручну. Підкреслили респонденти й необхідність допрацювання підручників аби вони відповідали сучасним нормам, залучення інформаційних та мультимедійних технологій, а також додавання життевих прикладів і спрощення формулювань для чіткого розуміння інформації (рис. 4).

Більшість студентів відповіли, що наявні в них електронні підручники не задовольняють їхні освітні потреби, аргументувавши це тим, що найчастіше індормація подана дуже сухо й нецікаво, а скан-копії не дозволяють повноцінно шукати, виділяти, копіювати текст, тому вони часто дивляться тему й шукають клікабельний текст в інтернеті. Не вистачає кольорів та схем також (рис. 5).

У 2018 році Міністерство освіти й науки України опублікувало наказ про затвердження Положення про електронний підручник у якому прописані основні вимоги й принципи створення такого інформпродукту [4]. Однак, на основі студентського навчального досвіду, які проходили опитування (рис. 6), ми робимо висновок, що підручники, якими користуються студенти не є повноцінними електронними посібниками, а лише цифровою копією паперових книжок. Тому, зважаючи на це, ми пропонуємо наступні зміни до процесу створення електронних підручників для вищої школи.

Безперечно, підручники мають бути побудовані відповідно до дидактичних засад: мають відповідати принципам наочності, об'єктивності, інтерактивності [5], індивідуального підходу, адаптованості до дисциплін [3], зв'язку із життям; враховувати вікові особливості студентського віку, а також особливості мислення по-

Розмір шрифту, швидкість роботи з електронним підручником

не потрібно тягати сумки, зручніше читати, робити закладки, не потрібне спеціальне освітлення, можна збільшити шрифт, має легкий доступ у будь-який час та неможливо забути вдома. Але інколи втомлюються очі і потрібно завжди мати зарядку

Доступність в будь який час та не займає місця.

економія часу, сил на те аби носити тяжкі сумки, електронні пристрої розширюють можливості роботи з підручником

Інтерактивність, зручність, безпека для здоров'я (немає загрози сколіозу через важкі сумки:)

Доступність, відкритість, безоплатність, матеріал викладається за певною галуззю знань, системно оновлюється.

Доступність

Доступно скрізь, не наносить шкоди довкіллю, не займає місце в сумці, можна регулювати шрифт аби добре бачити, робити скріншоти, виділяти текст

не носиш з собою зайву вагу, а є можливість користування через телефон/ планшет

екологічність, доступність (у тому числі й фінансова), відсутня додаткова вага, $є$ можливість шукати інформацію по слову, виділяти текст і робити закладки.

Доступність, швидкість пошуку та легкість використання

Рис. 3. Назвіть основні, на вашу думку, переваги електронного підручника будь-якого формату 
Хотілося б зменшити кількіть скан-копій з якими неможливо проводити такі дії як копіювання, виділення тощо. Корисним був би аудіосупровід та цікаве оформлення сторінок

мені не вистачає аудіоформату.Хоча деякі програми й дозволяють автоматичне читання тексту, але не українською мовою. Також часто

Необхідно зробити їх повноцінними, з гіперпосиланнями, залученням сучасних технологій та дотриманням норм

я б додала можливість проходити тести чи завдання в електроній формі для закріплення знань

Додала би спеціальні мультимедійні та ігрові технології

Єдина програма,спрощення функціоналу пошуку того або іншого матеріалу

Рис. 4. Як би Ви удосконалили електронні підручники, якими користуетесь зараз?

Джерело: опитування студентів в гугл-фбормі

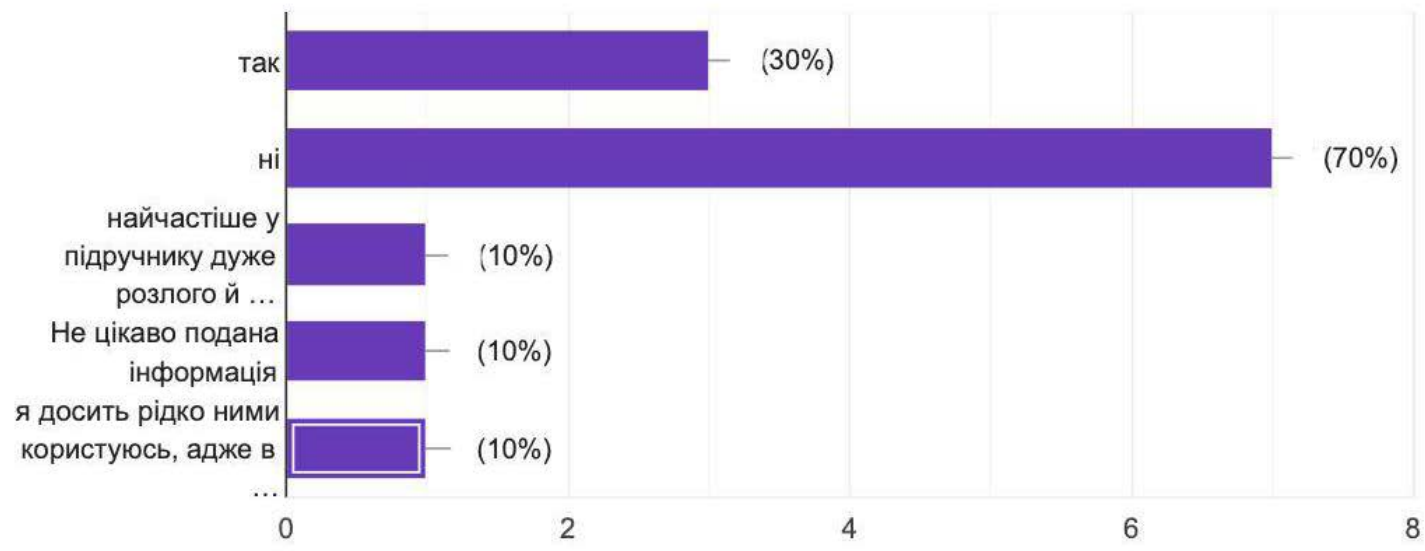

Рис. 5. Чи задовольняють наявні у Вас електронні підручники Ваші освітні потреби? (у графі "інші" зазначте чому)

Джерело: опитування студентів в гугл-бормі

колись у дитинстві я навчалась за допомогою ігор на дисках (англійська та історія) мені здається, що було б цікаво розробити якісь схожі програми для засвоєння дисциплін.

Ніколи про це не думала.

як на мене, такий підручник схожий на електронний курс, але там не потірбно нічого окремо скачувати

Зручний, цікавий, корисний, із грамотним застосуванням сучасних цифрових технологій

Доступність для відтворення на будь яких гаджетах.

Програмний,простий у користуванні та у доступній формі информація

Яскравий, схематичний, інтерактивний

мені хотілося 6 аби підручник був як додаток у смартфоні з різними цікавим и завданнями, кольоровими схемами, прикладами з життя, аудіо й відеоматеріалами.

Підручник не відсканований, а створений відповідно до норм та сучасних технологій. Використання кодів, посилань, доповненої реальності тощо

Рис. 6. Яким Ви бачите ідеальний електронний підручник? 
коління “Z” i сприйняття (аудіали, візуали, дискрети). Зміст підручника має транслювати зміст навчальної програми, мати мотиваційний та інформаційний компонент, сприяти не лише засвоєнню знань, а й нових компетентностей, виконувати розвивальну та виховну функцію.

Електронні підручники, побудовані на цих засадах, мають змінити формат зі звичайного документу на інтерактивний додаток з використанням мультимедійних технологій. Для того аби реалізувати цю мету, необхідно забезпечити достатній рівень володіння ІКТ грамотністю фрахівців, які займаються розробкою електронних посібників.

Розробка нових електронних посібників для вищої школи потребуе також і забезпечення викладачів технічними ресурсами та спеціалізованими платформами, де вони могли б займатися виготовленням інфрормаційних продуктів безкоштовно, адже зараз більшість якісних програм потребують чималу платню, тому, на нашу думку, фрінансування такої діяльності потребує додаткових пропозицій.

Особливостями нового формату електронного підручника, який відрізнятиме його від скан-копій, якими користуються студенти зараз, окрім розробки інфопродукту на спеціалізованій платорормі, є також і необхідність подавати текст змістовими короткими блоками без заангажування сторінок сухим текстом, 3 гіперпосиланнями й можливістю пошуку абзаців по ключовим словам; сторінки мають бути кольоровими, важлива інформація виділена, наявні ілюстрації й приклади з життя; до кожної теми наявні аудіо або відео супровід для тих, хто легше сприймає інформацію на слух, має особливі освітні потреби або не має достатньо часу для читання; тести для самоконтролю мають бути присутніми після кожної теми й одразу показувати бал з поясненням помилок, а розгорнуті відповіді надсилатися викладачу на перевірку автоматично; має бути можливість матеріал безпосередньо в додатку помічати для викладача як незрозумілий з проханням надати пояснення; вся рекомендована література має містити посилання на документи; мають бути посилання на аудіо й відеоматеріали, які доповнюють зміст блоку, а також завдання до цих форматів ознайомлення з темою; використані ігрові й інтерактивні технології (посилання на навчальні ігри, можливість вивчати матеріал з одногрупниками в групах виконуючи цікаві завдання, деякі завдання можуть бути розроблені у форматі симуляторів (наприклад, для студентів спеціальності педагогіка це можуть бути симулятори вчителя); студентам корисною була б можливість надсилати свої домашні завдання одразу в кінці теми; наявність можливості виділяти кольорами текст, ділитися 3 одногрупниками й ставити власні замітки, які за бажанням можна поширювати для всіх і в такий спосіб навчати одні одних; має бути доступний формат і можливість читати матеріал в режимі офрлайн; наявність розгорнутих інструкцій, доповненої реальності; можливість викладачам і студентам (за схваленням модератора-викладача) додавати й оновлювати інорормащію; можливість викладачам адаптувати завдання для студентів згідно 3 їхніми психологічними особливостями реалізуючи принцип індивідуального підходу; такі електронні підручники мають бути адаптованими під різні операційні системи й бути доступними для завантаження у вигляді додатку. Власне, новий вид електронного підручника має перестати бути схожим на звичайну книжку, це скоріше вже удосконалена версія електронного курсу, яка здатна справді зацікавити студентів i зробити їхній навчальний процес захопливим і продуктивним.

Отже, опитування студентів показують, що традиційні підручники вже перестали бути основним ресурсом для навчальної роботи. Студенти все частіше задовольняють свої освітні потреби за допомогою інтернет-джерел. I хоча більшість студентів відповіли, що їм складно уявити життя без паперових підручників, однак вони вважають, що розвиток сучасних індормаційних технологій і необхідність зберегти навколишне середовище рано чи пізно витіснить масове використання природних ресурсів для забезпечення освітніх потреб у галузі підручникотворення. Тож, ми вважаємо, що сучасний електронний підручник має значно видозмінитися аби відповідати всім вимогам нового покоління.

Такі зміни сприятимуть не тільки кращому засвоєнню знань, а зростанню інтересу молоді до навчання. До того ж подача матеріалу відповідно до особливостей сучасного мислення підвищить рівень якості освіти.

Висновки. Питання розробки єдиних стандартів і вимог до створення електронних підручників і досі лишається маловивченим в Україні.

Перспективними $є$ подальші дослідження й розробка електронних ресурсів, які могли б забезпечити викладачів зручним інструментаріем для створення підручників. Важливим, на наш розсуд, є також і питання підготовки та моніторингу готовності фрахівців, які планують займатися створенням інформаційних електронних продуктів для забезпечення освітніх потреб.

\section{Список літератури:}

1. Зарішняк I. М. Особливості навчання покоління Z. Вісник студентського наукового товариства Донецького національного університету імені Василя Стуса. 2019. Т. 2. С. 212-217.

2. Касьянова О. М. Парадигмальний підхід до розвитку теорії та практики освіти. Східноєвропейський журнал внутрішньої та сімейної медицини. 2017. № 1. С. 89-94.

3. Кухарський В. М., Осередчук О. А. Електронний підручник в українській вищій освіті: від ідеї створення до реалізації. Вісник Національного університету «Львівська політехніка». 2017. С. 84-90.

4. Про затвердження Положення про електронний підручник : Наказ МОН України від 02.05 .2018 р. № 440 : станом на 12 лип. 2019 р. URL: https://zakon.rada.gov.ua/laws/show/z0621-18

5. Шлапак Ю. Електронний підручник (посібник): стан і перспективи в Україні. Наукові праці Національної бібліотеки України ілені В.I. Вернадського. 2018. Вип. 49. С. 69-82. 


\section{References:}

1. Zarishniak I. M. (2019) Osoblyvosti navchannia pokolinnia Z [Features of learning generation Z]. Visnyk studentskoho naukovoho tovarystva Donetskoho natsionalnoho universytetu imeni Vasylia Stusa, pp. 212-217.

2. Kasianova O. M. (2017) Paradyhmalnyi pidkhid do rozvytku teorii ta praktyky osvity [Paradigmatic approach to the development of theory and practice of education]. Skhidnoievropeiskyi zhurnal vnutrishnoi ta simeinoi medytsyny, no. 1, pp. 89-94.

3. Kukharskyi V. M., Oseredchuk O. A. (2017) Elektronnyi pidruchnyk v ukrainskii vyshchii osviti: vid idei stvorennia do realizatsii [Electronic textbook in Ukrainian higher education: from the idea of creation to implementation]. Visnyk Natsionalnoho universytetu "Lvivska politekhnika", pp. 84-90.

4. Pro zatverdzhennia Polozhennia pro elektronnyi pidruchnyk [On approval of the Regulations on the electronic textbook]: Nakaz MON Ukrainy vid 02.05.2018 r. № 440: stanom na 12 lyp. 2019 r. Available at: https://zakon.rada.gov.ua/laws/show/z0621-18

5. Shlapak Yu. (2018) Elektronnyi pidruchnyk (posibnyk): stan i perspektyvy v Ukraini [Electronic textbook (manual): s tatus and prospects in Ukraine.]. Naukovi pratsi Natsionalnoi biblioteky Ukrainy imeni V.I., vol. 49, pp. 69-82. 